Article

\title{
Cost-Effectiveness of Black Soldier Fly Larvae Meal as Substitute of Fishmeal in Diets for Layer Chicks and Growers
}

\author{
Esther Khayanga Sumbule 1,2, Mary Kivali Ambula ${ }^{2}$, Isaac Maina Osuga ${ }^{3}$, Janice Ghemoh Changeh ${ }^{4}$, \\ David Miano Mwangi ${ }^{5}$, Sevgan Subramanian 1(1), Daisy Salifu ${ }^{1}$, Peter A. O. Alaru ${ }^{5}$, Macdonald Githinji ${ }^{5}$, \\ Joop J. A. van Loon ${ }^{6}$, Marcel Dicke ${ }^{6}(\mathbb{D})$ and Chrysantus M. Tanga ${ }^{1, *} \mathbb{( 1 )}$
}

Citation: Sumbule, E.K.; Ambula, M.K.; Osuga, I.M.; Changeh, J.G.; Mwangi, D.M.; Subramanian, S.; Salifu, D.; Alaru, P.A.O.; Githinji, M.; van Loon, J.J.A.; et al. Cost-

Effectiveness of Black Soldier Fly Larvae Meal as Substitute of Fishmeal in Diets for Layer Chicks and Growers. Sustainability 2021, 13, 6074. https://doi.org/10.3390/su13116074

Academic Editors: Lars Olav Eik and Marc A. Rosen

Received: 8 March 2021

Accepted: 18 May 2021

Published: 28 May 2021

Publisher's Note: MDPI stays neutral with regard to jurisdictional claims in published maps and institutional affiliations.

Copyright: (c) 2021 by the authors. Licensee MDPI, Basel, Switzerland. This article is an open access article distributed under the terms and conditions of the Creative Commons Attribution (CC BY) license (https:// creativecommons.org/licenses/by/ $4.0 /$ )
1 International Centre of Insect Physiology and Ecology (icipe), P.O. Box 30772, Nairobi 00100, Kenya; esthersumbule@gmail.com (E.K.S.); ssubramania@icipe.org (S.S.); dsalifu@icipe.org (D.S.)

2 Department of Animal Sciences, Egerton University, P.O. Box 536, Njoro 20115, Kenya; m.ambula@egerton.ac.ke

3 Department of Animal Science, Jomo Kenyatta University of Agriculture and Technology, P.O. Box 62000, Nairobi 00200, Kenya; isaac.osuga@jkuat.ac.ke

4 Centre for African Bio-Entrepreneurship (CABE), P.O. Box 25535, Nairobi 00603, Kenya; janiceghemoh@yahoo.com

5 Non-Ruminant Research Institute (NRI), Kenya Agricultural and Livestock Research Organization (KALRO), P.O. Box 57811, Naivasha 00200, Kenya; davidmianomwangi@gmail.com (D.M.M.); Peter.Alaru@kalro.org (P.A.O.A.); macgithinji@gmail.com (M.G.)

6 Laboratory of Entomology, Plant Sciences Group, Wageningen University, P.O. Box 16, 6700 AA Wageningen, The Netherlands; joop.vanloon@wur.nl (J.J.A.v.L.); marcel.dicke@wur.nl (M.D.)

* Correspondence: ctanga@icipe.org; Tel.: +254-20-8632151

\begin{abstract}
The acceptance of eco-friendly black soldier fly larvae meal (BSFLM) as sustainable alternative protein ingredient in poultry feeds continues to gain momentum worldwide. This study evaluates the impact of BSFLM in layer chick and grower diets on the growth, carcass quality and economic returns. Mean weekly weight gain and total live weight per chick and grower varied significantly. The highest final weight gain was achieved when birds were provided diet with $25.6 \%$ BSFLM. Average daily feed intake (ADFI), average daily weight gain (ADG) and overall weight gain of the chick varied significantly, except for the feed conversion ratio (FCR). For grower birds, ADFI, ADG, FCR and overall weight gain did not vary significantly across the various feeding regimes. The weight of the wings and drumsticks had a quadratic response with a maximum weight obtained at $33 \%$ inclusion of BSFLM. The weight of the internal organs were not significantly affected by dietary types. Positive cost-benefit ratio and return on investment was recorded for diet types with higher BSFLM inclusion levels (>75\%). Diets with $25 \%$ and 100\% BSFLM inclusion were the most suitable and cost-effective, respectively. Thus, BSFLM represents a promising alternative source of protein that could be sustainably used in the poultry industries.
\end{abstract}

Keywords: black soldier fly; insect-based feed formulation; chicken layers; carcass and organs yield; profitability; sustainable intensification

\section{Introduction}

Poultry farming is one of the fastest livestock sub-sector that has rapidly grown in recent decades globally. The fast-growing poultry sector continues to attract formation of small-scale farmer cooperatives across the world, employing millions of people directly in the production and marketing, and indirectly through linkages with input suppliers (dayold-chicks, feeds, and veterinary services) [1]. Due to the rapid growth in the poultry sector, poultry farming has become a much attractive agribusiness to resource poor communities because of they require low starting capital, space and maintenance costs [1]. This demand in turn is driven by rapid economic growth as a result of the alarmingly growing population that has created an increasing need to consume more animal proteins [2]. The demand in 
developing countries for poultry products is projected to increase by $70 \%$ to feed 9.2 billion people worldwide by 2050 [3], thus putting even more pressure on the need to produce more animal proteins such as poultry eggs and meat.

Isa Brown (IB) chicken is one of the most common commercial layers bred and supplied to enfranchised local companies for multiplication worldwide. In many countries, the current focus is to upscale improved hybrid layer birds to smallholder households [2] because they are commercially highly productive and profitable. The IB chicken are considered an excellent bioconverters of compounded feeds to high quality eggs, consume a relatively low amount of feed and yet produce more eggs with better shell quality than other common layer breeds [4]. Thus, the poultry farmers make very quick returns on investment because of the short generation time required before the hen lays eggs. Although, the fast-rising section continued to attract formation of many small-scale farmer co-operatives across different countries, the lack of high-quality feed has hampered most of the birds from being able to express their full genetic egg laying potential.

Good nutrition is key for efficient and profitable poultry production but the high price of poultry feeds, which represents over 70 percent of total cost of production, has hampered the sector from realizing its full potential $[5,6]$. This cost is mainly driven by the growing scarcity of feed protein ingredient resources like fishmeal (FM) and soybean [7]. The prices of fish and soya bean have doubled globally during the last 5 years [7], leaving farmers with very limited profit margins. Furthermore, FM in many countries have been reported to be adulterated, leading to lower quality being available in the market. Low crude protein (CP) values ranging from $40.3 \%$ to $55.1 \%$ DM have commonly been reported against the expected $\mathrm{CP}$ content of $>65 \%$ DM of FM [8-10]. Continued dependence on FM and SBM for poultry feed is not a sustainable option, especially for smallholder farmers, thus necessitating the search for sustainable alternatives such as insect-based larval proteins [5,11].

In recent years, the utilization of insect meal as high-quality ingredients in chicken, pig and fish diets has grown rapidly $[7,12,13]$. Insects have high, good quality protein contents and can be mass produced with a low environmental footprint due to low generation of greenhouse gases [14]. The use of insect meals in animal diets is economically more competitive compared to diets containing conventional protein ingredients in poultry diets [7]. Morever, consumers have also been reported to accept products from livestocks reared on compounded feeds containing insect meal [15].

Hermetia illucens L is commonly called black soldier fly (BSF), are potentially low-cost nutrient-rich alternative protein source, that is similar or superior in protein quality to FM and plant sources $[16,17]$. The processed larvae of this insect is rich in nutrients such as crude protein content $(38.5-62.7 \%)$ with well-balanced amino acids profile, good quality fatty acids (14.0-39.2\%) and micronutrients such as iron and zinc $[7,11,13,17]$. However, the nutritional status of these insects might vary depending on the species, developmental stage, and rearing substrates $[18,19]$. Several studies on the use of BSF larvae meal (BSFLM) in commercial feeds have largely focused on broiler [7], pig [13] and fish [12]) rather than layers. In literature, few studies on chicken layers have largely focused from the point of egg laying both for non-defatted BSFLM [20] or defatted BSFLM [21,22] based feeds. Also, chick, pullet, and layer birds, each has its own specific nutritional requirements, which must be considered when formulating their feed [23]. The studies described illustrated differences in body weight only at the onset of egg production because it is a major factor influencing the efficiency of egg production [20-22]. Although, laying hen are not raised for meat, the lack of information on the growth of the visceral organs could have a detrimental impact on egg productivity. For example, the weights of some visceral organs have been shown to be affected by dietary treatment [24]. Also, during feed restriction or change, the physical development of birds usually gives priority to the development of the internal organs, which are capable of recovering more quickly than other parts of the body [25]. According to Obeng et al. [26], changes of internal organs in growing birds could improve or hinder the utilization rate of energy, protein, amino acids, and other nutrients required to enhance their performance and resistance to many diseases. Globally, the effects of diets 
with varying inclusion levels of non-defatted BSFLM on IB chick and pullet (growers) are less well understood, though these developmental stages of the birds are considered to be highly susceptible to changes in dietary nutrients [24]. Therefore, the aim of this study was to evaluate differences in performance, feed utilization efficiency, body weight composition (carcass parts and internal organ development) and potential returns of investment of layer IB chick and grower bird fed ad libitum on diets with strategically inclusion levels of non-defatted BSFLM.

\section{Materials and Methods}

\subsection{Ethical Approval}

Ethical approval for the study was provided by the Institutional Animal Care and Use Committee (IACUC) of Kenya Agricultural and Livestock Research Organization (KALRO)-Veterinary Science Research Institute (VSRI); approval Code No.: KALROVSRI/IACUC019/30082019.

\subsection{Experimental Facility}

The experiments were conducted at the Poultry Research Unit of the Kenya Agricultural and Livestock Research Organisation (KALRO), Naivasha. We ensured adequate care and the conditions of the chickens were maintained following the procedures established by the Federation of Animal Science Societies [27]. The facility is located at $1800 \mathrm{~m}$, above sea level, $\left(0^{\circ} 43^{\prime} 12.85^{\prime \prime} \mathrm{S}, 36^{\circ} 25^{\prime} 42.71^{\prime \prime} \mathrm{E}\right)$ and receives mean annual rainfall of $1000 \mathrm{~mm}$ and has an ambient temperature ranging from 17 to $22{ }^{\circ} \mathrm{C}$.

\subsection{Experimental Birds and Housing}

Before commencement of the experiment, 250 one-day-old female IB chicks had an initial average body weight of $36.39 \pm 0.18 \mathrm{~g}$ when sourced from Kenchic Limited, Nairobi, Kenya. During the first two weeks of acclimatization, all the 1-day old birds (chicks) were kept together in a brooder, which was a round deep litter floor covered with a $7.6 \mathrm{~cm}$-thick layer of wood shavings bedding. The area was fitted with 250 Watts infra-red bulbs to provide heating during the brooding period. For a period of 14 days, the young birds were provided the control (100\% FM inclusion ratio) diet and water ad libitum for 14 days. However, birds that showed sign of deformity or weakness ( 25 chicks) were carefully removed. After14 days, they were weighed and kept in different floor pens $(1 \mathrm{~m} \times 1 \mathrm{~m})$ each with five chicks. The chicks were assigned randomly to one of the five feeding regimes using completely randomized design throughout the entire developmental feeding phase. The pens were constructed in a house with cemented floor and separated from each other using wire mesh. Each experimental set-up was replicated nine times. Plastic feeders (73 $\mathrm{cm}$ by $26 \mathrm{~cm}$ width by 48 height) with open top and 8 small holes were provided to allow the birds access feeds. A 3 litre plastic drinking containers were placed in each chicken pen. The birds were given access to both feed and clean water ad libitum daily. The conditions inside the rearing facility were kept at $30 \pm 1{ }^{\circ} \mathrm{C}$ with relative humidity (RH) of $70 \pm 2 \%$. Within the first 4 weeks, 24 h of lighting was used to stimulate feed and water intake among the chicks. This was later followed by gradual decrease of hours of lighting to adapt to natural conditions with dark: light cycle of $12 \mathrm{~h}: 12 \mathrm{~h}$ by the end of chick stage. Further lighting conditions were maintained with dark: light cycle of 12:12 h throughout the grower phase.

The vaccination programme of the birds followed the generally agreed guidelines for the prevention of any disease-causing bacteria/virus that could build up by boosting the birds' immunity [28]. Vitamins were administered in water each time a new batch of feed was introduced and after vaccination [28]. All drinkers were cleaned daily, and clean water offered to the birds every morning. Feeds were placed in plastic feeders each morning at 08:30 h. Sawdust were used as bedding in the pens and changed every 3 weeks to avoid ammonia build up and bacterial infection. 


\subsection{Determination of Nutrient Composition in Feed Ingredient and Diet Types}

All ingredients required for the formulation of the various diet types for both the chicks (Table 1) and pullets (grower) (Table 2) were sourced from well-known feed miller in the region, Josiche General Traders Ltd. (Nakuru, Kenya). The larvae of BSF used for the feeding experiment were obtained from the International Centre of Insect Physiology and Ecology (icipe), located in Nairobi, Kenya. The larvae were raised on barley spent grains obtained from the Kenya Breweries Limited. The conditions of the production facility were kept at $28 \pm 1{ }^{\circ} \mathrm{C}$, relative humidity of $60-70 \%$ and 12: 12 (light: dark) photoperiod. Once the larvae became 5 th instars, they were harvested and washed by deeping them in a container boiling water $\left(84^{\circ} \mathrm{C}\right)$ for $8-10 \mathrm{~min}$. Thereafter, the larvae were dried using stainless-steel trays in a food drying machine (Model: CT-C-III, Henan, China) at $120^{\circ} \mathrm{C}$ for $2 \mathrm{~h} 30 \mathrm{~min}$ to ensure that the processed larvae were safe for incorporation into animal feed. Several studies to date have raised concerns of the safety levels of H. illucens due to the contaminated nature of the rearing substrates [29,30], despite the excellent nutritional properties.

The sterilized and dried larvae were then ground into powder and mix up with other raw materials to formulate five diet types for the chick and grower pullets. Calculated estimate of the ingredients used in the formulated diets followed the nutrient requirements guidelines for chicks and grower [23]. The insect meal was used to replace FM partially and completely at various inclusion levels: Diet 1 (control) (100\% FM + 0\% BSFLM); Diet 2 (75\% FM + 25\% BSFLM); Diet 3 (50\% BSFLM + 50\% FM); Diet 4 (75\% BSFLM + 25\% FM) and Diet $5(100 \%$ BSFLM $+0 \%$ FM). The diet formulation was based on BSFLM crude protein (CP) content of $46.8 \%$ dry matter [13]. Average CP content of fishmeal was $47.7 \%$, which is within the range commonly reported in Kenya against the expected CP content of $>65 \%$ DM [8-10]. All diets for the entire experimental period were formulated at once by Josiche General Traders Ltd. following standard protocols to meet the nutrient requirements of the birds [23]. The slight variation observed in nutrient values presented in Tables 1 and 2, is a clear shortcoming, which might be attributed to processing procedures. Though, the method described above is commonly used in Sub-Saharan Africa, future research should formulate poultry diet based on standardized ileal digestibility (SID) of amino acids (AA) and ideal protein concept as described by Zhang and Adeola [31]. This is because insect meal, particularly BSFLM has been shown to exhibit low and variable sulphur amino acids (Methionine and Cysteine) concentration, that are the least digestible [32,33].

Thereafter, comprehensive analytical estimates of the nutrient quality of the formulated diets were also undertaken to ensure the crude protein levels for each treatment diet was within the acceptable values for chick and grower birds before the commencement of the experiments as described below. The method described by chia et al. [13] was used to determine the dry matter content of the diets based on gravimetric water loss. Using a muffle furnace the ash content was established by ignition of diets at 550-degree celcius $\left({ }^{\circ} \mathrm{C}\right)$. Samples were sent to Crop Nutrition (CROPNUTS) Laboratory Services Ltd., Kenya for analysis, whereby the diets were subjected to electromagnetic scan using absorbance mode in near infrared (NIR) spectroscopy. Standard laboratory procedures were used to determine the protein content, fat content, starch content, lipid (fat), acid detergent fibre, sugar, neutral detergent fibre, and digestibility values [34-37]. Metabolizable energy of diets were calculated according to recommended procedures described by NRC [23], Rosales et al. [38], Núñez-Sánchez et al. [39] and De Marco et al. [40].

The amino acids in the formulated diet types and the insect meal were analyzed by AMINOLab ${ }^{\circledR}$ (Evonik Industries, Hanau, Germany) using conventionally acceptable methods [41-46] and the results are presented in Tables 1 and 2. The mineral composition of the diets was analyzed by CROPNUTS, which included boron, calcium, cobalt, copper, iron, manganese, magnesium, molybdenum, potassium, phosphorus, sodium, sulphur and zinc, [47-50]. The results of the diets for the chicks and the growers are presented in Tables 3 and 4 , respectively. 


\subsection{Performance of the Birds Fed on Various Diet Types}

The initial weight of each bird per cage (replicate) was taken before the commencement of the experiment. On a weekly basis, the total weight gain of each bird was recorded using a digital electronic scale (TXB6201L, Shimadzu corporation, Kyoto, Japan) and average daily feed intake (ADFI), feed conversion ratio (FCR) and average daily weight gain (ADG) were calculated weekly. The final weight, overall weight gain and number dead birds during the entire experimental period were also recorded. This was performed for both chick ( $0-8$ weeks) and grower ( $8-20$ weeks) birds.

\subsection{Evaluation of the Carcass Yeild and Organs of Birds Fed on various Diet Types}

Twenty-five birds randomly selected from the five treatments (five from each diet type) and slaughtered at the age of 20 weeks carefully following all the strict guidelines of animal welfare [13]. This exercise was undertaken to assess the influence of various diet types on the visceral organs (liver, kidney, gizzard, and heart) development and carcass yield (thighs, breast, wings, and drumsticks) of the birds. Previous study by Leeson and Summers [51] have shown that the body of birds between 15 to 19 weeks of age (i.e., before on-set of egg production) can significantly influence egg weight during the egg laying phase of the hen. Prior to the slaughtering process, selected birds were starved for $12 \mathrm{~h}$ and weighed individually to determine live body weight after slaughtering. The birds were killed using an electric stunner on a rotating bleeding stainless steel table. An electrically heated water bath was used for scalding at $60^{\circ} \mathrm{C}$. The feathers of the birds were removed mechanically. The dressed carcass weight of each bird was taken after removal of the head, feet, and internal organs.

\subsection{Economic Analysis of Birds Fed on Various Diet Types}

The approach of return on investment (RoI) and cost-benefit ratio (CBR) were utilized to assess the economic implications of substituting fishmeal with insect meal in the diets for the birds [13]. Total costs comprised of medication, feed cost, human labor, housing, electricity, water, feeders, and chicken drinkers. The cost of feed was calculated based on the quantities of each ingredient added in each dietary treatment multiplied by the respective unit prices at the time of the experiment. The difference in ratio of production revenue and total production cost was used to account for the CBR and values observed to be more than 1 implied that the benefits of production was greater than that of the production costs and vice versa. Return on investment was used to measure the financial gain/loss and higher values were considered to be better representation of the RoI [7,52].

The profit $(\mathrm{Pr})=$ selling price per birds $(\mathrm{Sp})$ (amount at final market size or weight)-cost price of feed consumed per chicken $(\mathrm{Cp}) ; \mathrm{CBR}=\mathrm{Sp} / \mathrm{Cp} ; \mathrm{RoI}=\mathrm{Pr} / \mathrm{Cp} \times 100$. The final body weight, $\mathrm{Sp}, \mathrm{Pr}, \mathrm{CBR}$ and RoI were expressed as mean \pm standard error of the mean.

\subsection{Statistical Analysis}

Polynomial regressions were employed to evaluate the influence of incorporating BSFLM in the diet types and the control diet (\%BSFLM $+100 \% \mathrm{FM})$ on different parameters (feed intake, final weight gain, daily weight gain, live weight, dressing weight, weight of internal organs, FCR and economics) fed to the birds. Given five treatment levels; $0 \%$, $25 \%, 50 \%, 75 \%$ and $100 \%$ increasing levels of BSFLM, we evaluated the linear, quadratic, cubic and quartic effects of diet on the measured response variables. We used the polynom package to estimate the maxima of quadratic polynomial curves [53] whose regression coefficients were significant at $\alpha=0.05$. The data on cost and profit were subjected to ANOVA R software packages (version 3.5.1).

\section{Results}

\subsection{Determination of Nutrient Composition in Feed Ingredient and Diet Type}

The composition of the raw materials and BSF amino acids used in the chick and grower diet types are shown in Tables 1 and 2, respectively. While the mineral and 
proximate composition of the chick and grower diet types for each treatment are presented in Tables 3 and 4, respectively. There was variation in the mineral content of the various diets for the chick and growers.

Table 1. Ingredient composition, amino acid content of insect meal and formulated experimental diets fed to the chick for a period of eight (8) weeks.

\begin{tabular}{|c|c|c|c|c|c|c|}
\hline Ingredient (\%) & BSFLM & $\begin{array}{c}\text { Diet } 1 \\
\text { (Control) }\end{array}$ & Diet 2 & Diet 3 & Diet 4 & Diet 5 \\
\hline Maize germ & & 60.0 & 60.0 & 60.0 & 60.0 & 60.0 \\
\hline Soybean meal & & 21.0 & 21.0 & 21.0 & 21.0 & 21.0 \\
\hline Fishmeal & & 10.0 & 7.5 & 5.0 & 2.5 & 0 \\
\hline BSFL & & 0.0 & 2.5 & 5.0 & 7.5 & 10 \\
\hline Vegetable oil & & 2.0 & 2.0 & 2.0 & 2.0 & 2.0 \\
\hline Limestone & & 5.0 & 5.0 & 5.0 & 5.0 & 5.0 \\
\hline Dicalcium phosphate & & 1.5 & 1.5 & 1.5 & 1.5 & 1.5 \\
\hline Iodized salt $(\mathrm{NaCl})$ & & 0.3 & 0.3 & 0.3 & 0.3 & 0.3 \\
\hline Layer premix ${ }^{a}$ & & 0.2 & 0.2 & 0.2 & 0.2 & 0.2 \\
\hline \multicolumn{7}{|c|}{ Calculated nutrient composition } \\
\hline Dry matter (\%) & 94.9 & 91.6 & 91.7 & 91.5 & 92.4 & 92.2 \\
\hline $\mathrm{CP}(\% \mathrm{DM})$ & 46.6 & 20.4 & 20.2 & 20.1 & 19.9 & 19.7 \\
\hline Energy (Kcal/kg DM) & & 3066.8 & 3078.8 & 3090.8 & 3102.8 & 3114.8 \\
\hline Crude fat $(\% \mathrm{DM})$ & & 5.1 & 5.2 & 5.4 & 5.2 & 5.6 \\
\hline Crude fibre (\% DM) & & 5.2 & 5.4 & 5.6 & 5.9 & 5.1 \\
\hline \multicolumn{7}{|c|}{ Essential amino acids (\% DM) } \\
\hline Methionine & 0.8 & 0.2 & 0.3 & 0.3 & 0.2 & 0.3 \\
\hline Met + Cys & 1.1 & 0.5 & 0.5 & 0.5 & 0.5 & 0.5 \\
\hline Lysine & 2.9 & 0.7 & 0.9 & 0.8 & 0.8 & 0.9 \\
\hline Threonine & 1.7 & 0.5 & 0.6 & 0.6 & 0.6 & 0.7 \\
\hline Arginine & 2.2 & 1.0 & 1.1 & 1.1 & 1.0 & 1.1 \\
\hline Isoleucine & 1.8 & 0.5 & 0.6 & 0.6 & 0.6 & 0.7 \\
\hline Luecine & 2.9 & 1.1 & 1.2 & 1.2 & 1.1 & 1.3 \\
\hline Valine & 2.6 & 0.7 & 0.8 & 0.8 & 0.8 & 0.9 \\
\hline Histidine & 1.3 & 0.4 & 0.4 & 0.4 & 0.4 & 0.5 \\
\hline Phenylalanine & 2.2 & 0.6 & 0.7 & 0.7 & 0.7 & 0.8 \\
\hline \multicolumn{7}{|c|}{ Non-essential amino acids (\% DM) } \\
\hline Glycine & 2.5 & 0.8 & 0.9 & 0.8 & 0.8 & 0.9 \\
\hline Cystine & 0.4 & 0.2 & 0.3 & 0.3 & 0.2 & 0.3 \\
\hline Proline & 2.4 & 0.8 & 1.0 & 0.9 & 0.9 & 1.0 \\
\hline Alanine & 3.0 & 0.8 & 0.9 & 0.9 & 0.9 & 1.0 \\
\hline Serine & 1.8 & 0.6 & 0.8 & 0.7 & 0.7 & 0.8 \\
\hline Aspartic acid & 3.9 & 1.2 & 1.5 & 1.5 & 1.4 & 1.6 \\
\hline Glutamic acid & 4.9 & 2.3 & 2.7 & 2.5 & 2.4 & 2.7 \\
\hline $\begin{array}{l}\text { BSFLM: Black soldier fly larval } \\
\text { Vit. D3:2,000,000 IU/ kg, Vit. E: } \\
\text { 20,000 mg, Folic Acid: } 550 \mathrm{mg} \\
120 \mathrm{mg} \text {, Manganese: } 63,000 \mathrm{mg} \\
2000 \mathrm{mg} \text {, Selenium: } 100 \mathrm{mg} \text { and } \\
\text { phosphate, FM-fishmeal, Diet } \\
\text { FM, Diet 4-75\% BSFLM and } 25\end{array}$ & $\begin{array}{l}\text { ' Super lay } \\
\text { mg, Vit. K3 } \\
\text { B12: } 6 \mathrm{mg} \\
\text { 23,000 mg } \\
\text { 120,000 mg } \\
\% \text { BSFLM, I } \\
\text { M and Diet }\end{array}$ & $\begin{array}{l}\text { premix cont } \\
2000 \text { mg, Vit } \\
\text { Choline chlc } \\
\text { zinc: } 63,000 \mathrm{r} \\
\text { BSFL-Black } \\
\text { et } 2-25 \% \text { BS } \\
-100 \% \text { BSFLI }\end{array}$ & $\begin{array}{l}\text { ts per } 2.51 \\
: 3500 \mathrm{mg} \\
\text { de: } 200,00 \\
\text { Copper: } \\
\text { ldier fly la } \\
\mathrm{M} \text { and } 75\end{array}$ & $\begin{array}{l}\text { Vit. (Vit } \\
\text { antother } \\
\text { mg, Lys } \\
4,000 \mathrm{mg} \\
\text { ae, Ca- } \\
\text { FM, Die }\end{array}$ & $\begin{array}{l}\text { in) A: } 8,00 \\
\text { Acid: } 6600 \\
: 350 \mathrm{mg} \text {, } \\
\text { obalt: } 100 \\
\text { cium, DCF }\end{array}$ & $\begin{array}{l}000 \mathrm{IU} / \mathrm{k} \\
\mathrm{ng}, \mathrm{Niaci} \\
\text { Tethionin } \\
\text { ng, Iodin } \\
\text {-Dicalciu }\end{array}$ \\
\hline
\end{tabular}


Table 2. Ingredients, amino acid content of insect meal and formulated diets fed to the grower for a period of 12 weeks.

\begin{tabular}{|c|c|c|c|c|c|}
\hline \multirow[b]{2}{*}{ Ingredient (\%) } & \multicolumn{5}{|c|}{ Diet Types } \\
\hline & $\begin{array}{c}\text { Diet } 1 \\
\text { (Control) }\end{array}$ & Diet 2 & Diet 3 & Diet 4 & Diet 5 \\
\hline Maize germ & 50.0 & 50.0 & 50.0 & 50.0 & 50.0 \\
\hline Pollard (wheat) & 19.0 & 19.0 & 19.0 & 19.0 & 19.0 \\
\hline Soybean meal & 13.0 & 13.0 & 13.0 & 13.0 & 13.0 \\
\hline Fishmeal & 10.0 & 7.5 & 5.0 & 2.5 & 0.0 \\
\hline BSFL & 0.0 & 2.5 & 5.0 & 7.5 & 10 \\
\hline Limestone & 5.5 & 5.5 & 5.5 & 5.5 & 5.5 \\
\hline Dicalcium Phosphate & 2.0 & 2.0 & 2.0 & 2.0 & 2.0 \\
\hline $\mathrm{NaCl}$ & 0.3 & 0.3 & 0.3 & 0.3 & 0.3 \\
\hline Layer premix & 0.2 & 0.2 & 0.2 & 0.2 & 0.2 \\
\hline \multicolumn{6}{|c|}{ Calculated nutrient levels } \\
\hline $\mathrm{CP}(\% \mathrm{DM})$ & 18.5 & 18.3 & 18.1 & 17.9 & 17.8 \\
\hline Energy (Kcal/kg DM) & 2905.4 & 2917.2 & 2929.4 & 2941.4 & 2953.4 \\
\hline Crude fat $(\% \mathrm{DM})$ & 5.3 & 5.1 & 5.9 & 5.7 & 5.6 \\
\hline Crude fibre (\% DM) & 4.8 & 5.0 & 5.2 & 5.4 & 5.6 \\
\hline \multicolumn{6}{|c|}{ Essential amino acids (\% DM) } \\
\hline Methionine & 0.3 & 0.3 & 0.3 & 0.3 & 0.3 \\
\hline Met + Cys & 0.6 & 0.6 & 0.6 & 0.6 & 0.6 \\
\hline Lysine & 1.1 & 1.1 & 1.1 & 1.1 & 1.1 \\
\hline Threonine & 0.7 & 0.8 & 0.7 & 0.7 & 0.8 \\
\hline Arginine & 1.3 & 1.4 & 1.3 & 1.3 & 1.3 \\
\hline Isoleucine & 0.8 & 0.8 & 0.8 & 0.8 & 0.8 \\
\hline Luecine & 1.5 & 1.6 & 1.5 & 1.5 & 1.5 \\
\hline Valine & 0.9 & 1.0 & 0.9 & 0.9 & 1.0 \\
\hline Histidine & 0.5 & 0.5 & 0.5 & 0.5 & 0.5 \\
\hline Phenylalanine & 0.9 & 1.0 & 0.9 & 0.9 & 0.9 \\
\hline \multicolumn{6}{|c|}{ Non-essential amino acids (\% DM) } \\
\hline Cystine & 0.3 & 0.3 & 0.3 & 0.3 & 0.3 \\
\hline Glycine & 0.8 & 0.9 & 0.8 & 0.8 & 0.9 \\
\hline Serine & 0.6 & 0.8 & 0.7 & 0.7 & 0.8 \\
\hline Proline & 0.8 & 1.0 & 0.9 & 0.9 & 1.0 \\
\hline Alanine & 0.8 & 0.9 & 0.9 & 0.9 & 1.0 \\
\hline Aspartic acid & 1.2 & 1.5 & 1.5 & 1.4 & 1.6 \\
\hline Glutamic acid & 2.3 & 2.7 & 2.5 & 2.4 & 2.7 \\
\hline
\end{tabular}

Super layer premix contents per 2.5 kg: Vit. (Vitamin) A: 8,000,000 IU/kg, Vit. D3:2,000,000 IU/kg, Vit. E: $3000 \mathrm{mg}$ Vit. K3: 2000 mg, Pantothenic Acid: $6600 \mathrm{mg}$, Vit B2: $3500 \mathrm{mg}$, Niacin: 20,000 mg, Folic Acid: $550 \mathrm{mg}$, Manganese: 63,000 mg, Vit. B12: 6 mg, Choline chloride: 200,000 mg, Lysine: 350 mg, Methionine: 120 mg, Iron: 23,000 mg, zinc: $63,000 \mathrm{mg}$, Copper: 14,000 mg, Cobalt: $1000 \mathrm{mg}$, Iodine: $2000 \mathrm{mg}$, Selenium: $100 \mathrm{mg}$ and BHT: 120,000 mg. BSFLM-Black soldier fly larval meal, Ca-calcium, DCP-Dicalcium phosphate; FM-Fishmeal; Diet 1-0\% BSFLM, Diet 2-25\% BSFLM and 75\% FM, Diet 3-50\% BSFLM and 50\% FM, Diet 4-75\% BSFLM and 25\% FM and Diet $5-100 \%$ BSFLM. 
Table 3. The proximate analysis and mineral content of chick diet types.

\begin{tabular}{|c|c|c|c|c|c|}
\hline \multirow[b]{2}{*}{ Mineral } & \multicolumn{5}{|c|}{ Diet Types } \\
\hline & $\begin{array}{c}\text { Diet } 1 \\
\text { (Control) }\end{array}$ & Diet 2 & Diet 3 & Diet 4 & Diet 5 \\
\hline Boron (ppm) & 12.2 & 13.1 & 13.8 & 12.2 & 12.8 \\
\hline Molybdenum (ppm) & 1.4 & 1.3 & 1.4 & 1.5 & 1.4 \\
\hline Iron (ppm) & 666.0 & 818.0 & 524.0 & 574.0 & 481.0 \\
\hline Copper (ppm) & 9.4 & 11.7 & 9.2 & 7.8 & 26.8 \\
\hline Zinc (ppm) & 70.8 & 70.6 & 63.1 & 54.8 & 67.0 \\
\hline Cobalt (ppm) & 0.4 & 0.8 & 0.3 & 0.2 & 0.3 \\
\hline Manganese (ppm) & 62.8 & 86.8 & 54.0 & 40.5 & 43.5 \\
\hline Sodium (ppm) & 1530.0 & 1550.0 & 1280.0 & 1790.0 & 1690.0 \\
\hline Sulphur (\%) & 0.2 & 0.2 & 0.2 & 0.2 & 0.2 \\
\hline Magnesium (\%) & 0.4 & 0.5 & 0.5 & 0.5 & 0.5 \\
\hline Potassium (\%) & 1.1 & 1.1 & 1.2 & 1.1 & 1.1 \\
\hline Phosphorus (\%) & 0.8 & 0.7 & 0.7 & 0.6 & 0.6 \\
\hline Starch $(\%)$ & 28.2 & 26.2 & 26.8 & 28.1 & 27.0 \\
\hline Ash $(\%)$ & 7.0 & 6.8 & 6.7 & 6.4 & 6.4 \\
\hline $\mathrm{CP}(\%)$ & 19.4 & 20.6 & 19.5 & 19.7 & 20.0 \\
\hline Oil (\%) & 5.81 & 6.11 & 5.62 & 5.3 & 5.51 \\
\hline $\operatorname{ADF}(\%)$ & 12.3 & 13.9 & 15.3 & 12.2 & 13.5 \\
\hline Calcium $(\%)$ & 4.5 & 4.5 & 3.3 & 3.5 & 3.2 \\
\hline NDF $(\%)$ & 27.7 & 32.2 & 34.2 & 31.3 & 34.4 \\
\hline Digestibility (NCGD) (\%) & 75.7 & 73.1 & 70.2 & 73.9 & 70.6 \\
\hline Metabolizable energy (Kcal/kg) & 2904 & 2875 & 2871 & 2845 & 2872 \\
\hline
\end{tabular}
Diet 3: $50 \%$ BSFLM + 50\%FM; Diet 4: 75\%BSFLM + 25\%FM; Diet 5: $100 \%$ BSFLM + 0\%FM; ppm = parts per million; NCGD = neutral cellulase gammanase digestibility.

Table 4. The proximate analysis and mineral content of grower diet types.

\begin{tabular}{cccccc}
\hline & \multicolumn{5}{c}{ Diet Types } \\
\cline { 2 - 5 } Parameter & Diet 1 & Diet 2 & Diet 3 & Diet 4 & Diet 5 \\
\hline Boron (ppm) & 6.3 & 7.5 & 7.2 & 6.4 & 6.4 \\
Molybdenum (ppm) & 1.4 & 1.2 & 1.3 & 1.0 & 0.8 \\
Iron (ppm) & 667.0 & 539.0 & 588.0 & 554.0 & 394.0 \\
Copper (ppm) & 10.0 & 17.7 & 12.0 & 16.8 & 11.9 \\
Zinc (ppm) & 80.7 & 70.9 & 70.3 & 58.4 & 71.3 \\
Cobalt (ppm) & 1.5 & 0.9 & 0.3 & 0.4 & 0.5 \\
Manganese (ppm) & 90.0 & 90.8 & 91.2 & 70.2 & 78.3 \\
Sodium (ppm) & 1640.0 & 1600.0 & 1530.0 & 1120.0 & 1140.0 \\
Sulphur (\%) & 0.2 & 0.2 & 0.2 & 0.2 & 0.2 \\
Magnesium (\%) & 0.5 & 0.5 & 0.5 & 0.5 & 0.5 \\
Potassium (\%) & 0.9 & 0.9 & 1.0 & 0.9 & 1.0 \\
Phosphorus (\%) & 0.9 & 0.9 & 0.7 & 0.6 & 0.6 \\
Starch (\%) & 29.7 & 32.0 & 29.8 & 29.6 & 26.9 \\
Ash (\%) & 9.8 & 9.7 & 8.7 & 12.9 & 8.1 \\
CP (\%) & 17.8 & 17.8 & 17.5 & 17.3 & 17.9 \\
Oil (\%) & 6.4 & 6.1 & 6.7 & 5.47 & 5.6 \\
ADF (\%) & 11.9 & 9.53 & 12.4 & 12.9 & 11.7 \\
Calcium (\%) & 5.4 & 4.6 & 4.5 & 6.6 & 3.0 \\
NDF (\%) & 32.5 & 29.5 & 34.2 & 34.7 & 33.8 \\
Digestibility (NCGD) (\%) & 75.0 & 77.9 & 74.1 & 72.8 & 74.3 \\
Metabolizable energy (Kcal/kg) & 2900 & 2900 & 2902 & 2904 & 2905 \\
\hline BSFyyyyy
\end{tabular}

BSFLM-Black soldier fly larval meal; FM—Fishmeal; Diet 1: 100\%FM + 0\%BSFLM; Diet 2: 75\%FM + 25\%BSFLM Diet 3: 50\%BSFLM + 50\%FM; Diet 4: 75\%BSFLM + 25\%FM; Diet 5: $100 \%$ BSFLM + 0\%FM. ppm = parts per million; NCGD = neutral cellulase gammanase digestibility. 


\subsection{Performance of the Birds (Chick and Grower) Fed on Various Diet Types}

The performance of the layer chicks fed on the various diets is presented in Table 5. In the starter phase of the chick, the regression analyses showed a significant linear decrease in final weight as well as overall weight with increase in substitution of FM with BSFLM $(p<0.001)$. For every percentage increase in BSFLM, the layer chicks lose $1.3 \mathrm{~g}$ of final weight and the same amount for overall weight gain. ADG and ADFI linearly decreased with increase in replacement of FM by BSFLM $(p<0.001)$ while FCR was not significantly affected (Table 5).

Table 5. Growth performance of Isa Brown layer chicks (8 weeks) and grower (12 weeks) when fed different experimental diet types.

\begin{tabular}{|c|c|c|c|c|c|c|c|c|}
\hline \multirow{2}{*}{ Parameter } & \multicolumn{5}{|c|}{ Dietary Treatments } & \multicolumn{3}{|c|}{ Polynomials } \\
\hline & Diet 1 & Diet 2 & Diet 3 & Diet 4 & Diet 5 & Linear & Quadratic & Cubic \\
\hline \multicolumn{9}{|c|}{ Chick stage } \\
\hline Bird initial weight (g) & 96.2 & 101.3 & 100.9 & 102.1 & 101.3 & - & - & - \\
\hline Bird final weight $(\mathrm{g})$ & $476.2^{\mathrm{a}}$ & $481.5^{\mathrm{a}}$ & $418.0^{b}$ & $414.7^{\mathrm{b}}$ & $346.7^{c}$ & $<0.001$ & 0.081 & 0.917 \\
\hline Bird overall weight (g) & $380.0^{\mathrm{a}}$ & $380.2^{a}$ & $317.1^{b}$ & $312.6^{b}$ & $246.3^{c}$ & $<0.001$ & 0.148 & 0.969 \\
\hline $\operatorname{ADG}(g)$ & $9.1^{\mathrm{a}}$ & $9.1^{\mathrm{a}}$ & $7.6^{b}$ & $7.4^{\mathrm{b}}$ & $5.9^{c}$ & $<0.001$ & 0.148 & 0.969 \\
\hline ADFI $(g)$ & $36.2^{\mathrm{a}}$ & $33.8^{\mathrm{a}}$ & $29.8^{b}$ & $27.7^{b, c}$ & $24.7^{c}$ & $<0.001$ & 0.779 & 0.726 \\
\hline FCR $(\mathrm{g} / \mathrm{g})$ & $3.17^{\mathrm{a}}$ & $2.78^{b}$ & $3.09^{b}$ & $2.68^{\mathrm{b}}$ & $3.29^{a}$ & 0.754 & 0.548 & 0.872 \\
\hline \multicolumn{9}{|c|}{ Grower stage } \\
\hline Bird initial weight (gram) & 476.2 & 481.5 & 418.0 & 414.7 & 346.7 & - & - & - \\
\hline Bird final weight (gram) & 1181.6 & 1264.6 & 1189.1 & 1139.6 & 1049.4 & 0.002 & 0.026 & 0.309 \\
\hline Bird overall weight (gram) & 705.4 & 783.2 & 771.0 & 724.9 & 702.6 & 0.504 & 0.057 & 0.257 \\
\hline ADG (gram) & 9.2 & 10.2 & 10.0 & 9.4 & 9.1 & 0.491 & 0.052 & 0.275 \\
\hline ADFI (gram) & 84.6 & 84.3 & 84.6 & 78.3 & 75.2 & 0.006 & 0.245 & 0.746 \\
\hline FCR & 1.64 & 1.45 & 1.44 & 1.52 & 1.40 & 0.194 & 0.253 & 0.358 \\
\hline
\end{tabular}

ADFI-Average daily feed intake, ADG-Average daily weight gain, FCR-Feed conversion ratio, T—treatment, MSE—mean squared error. BSFLM—Black soldier fly larval meal; FM—Fishmeal; Diet 1: 100\%FM + 0\%BSFLM; Diet 2: 75\%FM + 25\%BSFLM; Diet 3: 50\%BSFLM + 50\%FM; Diet 4: 75\%BSFLM + 25\%FM; Diet 5: 100\% BSFLM + 0\%FM. ${ }^{\mathrm{a}, \mathrm{b}, \mathrm{c}}$ Means in a row with different superscript letters are significantly different at $\alpha=0.05$, while means in row with similar superscript are not significantly different at $\alpha=0.05$.

The performance of grower birds is presented in Table 5. The final weight of the birds was observed to show a significant quadratic response to increasing inclusion levels of BSFLM with an estimated maximum of $25.6 \%$ BSFLM inclusion. Overall weight gain increased up to a maximum of $32.1 \%$. While ADG and FCR were not significantly affected by increasing inclusion levels of BSFLM. ADFI linearly decreased with inclusion levels of $\operatorname{BSFLM}(p=0.006)$ (Table 5).

Both the chicks and growers fed diet 2 had better average weekly weight gain than the others until the 10th week when a sharp decline in weight gain was observed (Figure 1). Remarkable decrease in weekly weight gain of the birds from the 14th week onward toward the onset of egg production was observed (Figure 1). The total weekly live weight per bird significantly varied for both the chicks $(p=0.002)$ and grower pullets $(p=0.021)$ (Figure 2$)$ fed on the various diets, though the trend was similar. There was a consistent live weight increase for both the chicks and growers when fed diet 2 (75\%FM + 25\%BSFLM), followed by those fed diet $1(100 \% \mathrm{FM}+0 \% \mathrm{BSFLM})$ (Figure 2). Birds fed diet $5(0 \% \mathrm{FM}+100 \% \mathrm{BSFLM})$ had the lowest total weekly live weight throughout the chick and grower experimental phases (Figure 2). 


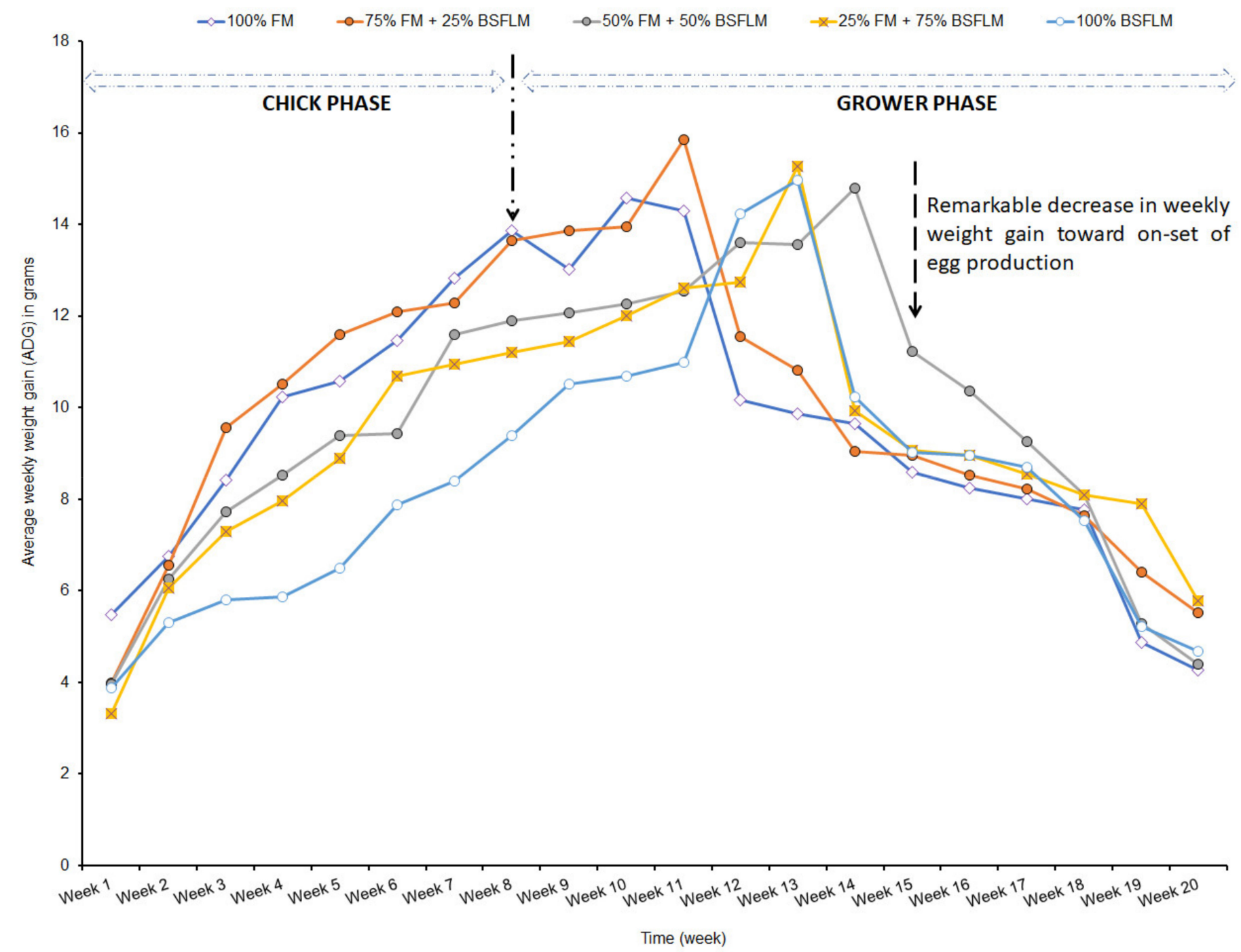

Figure 1. Average weekly weight gain (ADG) in grams of chicks and grower pullets fed on the various diets throughout the experiment. Diet 1: $100 \% \mathrm{FM}+0 \% \mathrm{BSFLM}$; Diet 2: 75\%FM + 25\%BSFLM; Diet 3: 50\%BSFLM + 50\%FM; Diet 4: 75\%BSFLM + 25\%FM and Diet 5: 100\% BSFLM + 0\%FM. 


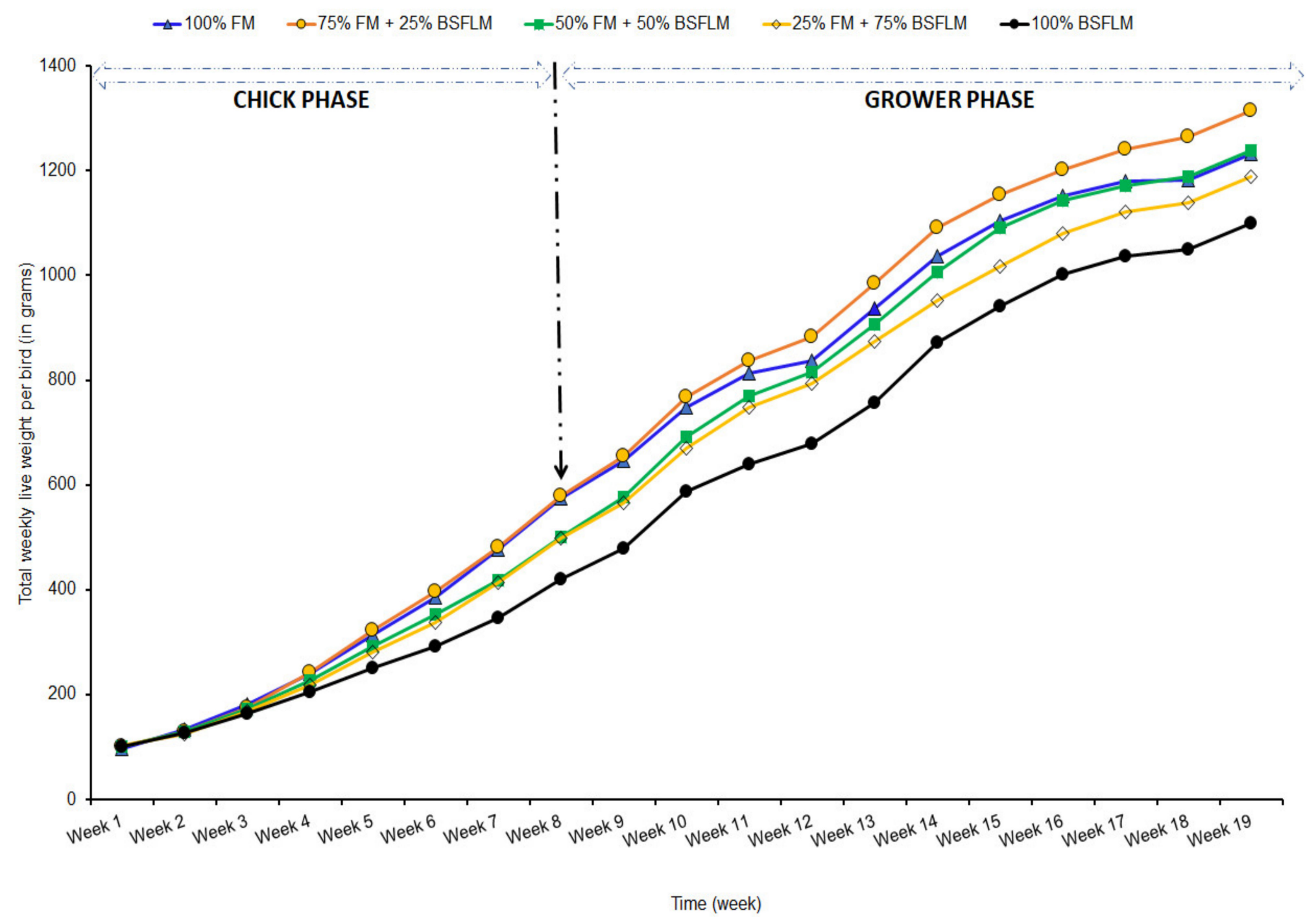

Figure 2. Total weekly live weight per chick and grower pullets fed on the various diets throughout the experiment. Diet 1: 100\%FM + 0\%BSFLM; Diet 2: 75\%FM + 25\%BSFLM; Diet 3: 50\%BSFLM + 50\%FM; Diet 4: 75\%BSFLM + 25\%FM and Diet 5: 100\% BSFLM + $0 \%$ FM. 


\subsection{Evaluation of the Carcass Yield and Organs of Birds Fed on various Diet Types}

The dressing percentage $(\%)$ or percentage carcass yield of the birds fed on various diet types was similar and ranged between $67-69 \%$. The carcasses weight of chicken provided diet containing 100\%BSFLM and 0\% FM showed the lowest weight (Table 6). The overall carcass weight demonstrated a significant quadratic response (quadratic effect; $p=0.021$ ) following increasing inclusion of BSFLM with maximum weight obtained at $29.3 \%$ BSFLM. The weights of carcass cuts namely wing, and drumstick had a comparable trend to the overall carcass weight. Maximum weight for wings was estimated at $32.4 \%$ BSFLM while maximum weight for drumsticks was obtained at 33.6\% inclusion of BSFLM, which then the weight decreased beyond these estimated percent inclusion. Increasing inclusion of BSFLM did not vary significantly for breast meat weight, liver, gizzard, heart, and kidney $(p>0.05)$ when birds were subjected to various diet types (Table 6).

Table 6. Carcass components weight (grams) and internal organs weight of different parts of grower layer hen fed on various experimental diet types.

\begin{tabular}{|c|c|c|c|c|c|c|c|c|}
\hline \multirow{2}{*}{ Body Parts } & \multicolumn{5}{|c|}{ Diet Types } & \multicolumn{3}{|c|}{ Polynomials } \\
\hline & Diet 1 & Diet 2 & Diet 3 & Diet 4 & Diet 5 & Linear & Quadratic & Cubic \\
\hline $\begin{array}{l}\text { Carcass } \\
\text { weight }\end{array}$ & $847.8^{\mathrm{a}, \mathrm{b}}$ & $922.6^{\mathrm{a}}$ & $900.8^{\mathrm{a}, \mathrm{b}}$ & $840.5^{b, c}$ & $806.0^{\mathrm{c}}$ & 0.030 & 0.021 & 0.187 \\
\hline \multicolumn{9}{|c|}{ Carcass components weight (g) } \\
\hline Thighs & $122.3^{a, b}$ & $131.9^{a}$ & $123.9^{\mathrm{a}, \mathrm{b}}$ & $110.8^{b, c}$ & $106.8^{c}$ & 0.002 & 0.078 & 0.083 \\
\hline Wings & $112.6^{b, c}$ & $126.3^{\mathrm{a}}$ & $119.9^{\mathrm{a}, \mathrm{b}}$ & $114.9^{b, c}$ & $108.1^{\mathrm{c}}$ & 0.091 & 0.009 & 0.131 \\
\hline Drumsticks & 107.8 & 117.9 & 116.5 & 110.8 & 105.6 & 0.361 & 0.026 & 0.332 \\
\hline Breast meat & 177.1 & 195.9 & 189.6 & 178.6 & 175.1 & 0.342 & 0.072 & 0.154 \\
\hline \multicolumn{9}{|c|}{ Internal organs weight $(\mathrm{g})$} \\
\hline Liver & 26.8 & 26.1 & 25.7 & 25.0 & 24.2 & 0.080 & 0.904 & 0.881 \\
\hline Gizzard & 44.3 & 39.8 & 42.2 & 38.4 & 36.1 & 0.094 & 0.889 & 0.590 \\
\hline Heart & 5.5 & 5.8 & 5.8 & 6.1 & 6.1 & 0.171 & 0.505 & 0.356 \\
\hline Kidney & 2.7 & 3.1 & 2.9 & 2.7 & 2.8 & 0.771 & 0.682 & 0.509 \\
\hline
\end{tabular}

a,b,c Means in a row with different superscript letters are significantly different at $\alpha=0.05$. Black soldier fly larvae meal (BSFLM); FMFishmeal; Diet 1: 100\%FM + 0\%BSFLM; Diet 2: 75\%FM + 25\%BSFLM; Diet 3: 50\%BSFLM + 50\%FM; Diet 4: 75\%BSFLM + 25\%FM and Diet 5: $100 \%$ BSFLM + 0\%FM. Birds were 20 weeks old at time of slaughter.

\subsection{Economic Analysis of Birds Fed on Various Diet Types}

The results of the return on investment (RoI) and Cost benefit ratio (CBR) are shown in Table 7. The cost of feed consumed by the chicks and growers showed considerable variation across the various diet types (Table 7). Live weight of the birds at sales was observed to differ significantly when fed on the different diets formulated with FM and BSFLM. The gross profit margin, CBR and RoI were also observed to vary significantly among the five diet treatments. The control diet (Diet 1) $(100 \% \mathrm{FM}+0 \% \mathrm{BSFLM})$ was the most expensive feed formulation for both the chicks and growers while diet $5(0 \% \mathrm{FM}+100 \%$ BSFLM) was the cheapest in terms of total feed cost and feed intake. There was a positive gain in profit when birds were fed on diet $5(0 \%$ FM $+100 \mathrm{BSFLM})$ and Diet 4 (25\%FM + 75\%BSFLM $)$ of 0.8 US\$ and 0.5 US\$, respectively. The calculated cost benefit ratio and RoI were observed to increase with increasing substitution of fish meal with BSFLM (Table 7). 
Table 7. Economic analysis of replacing FM with BSFL in Isa Brown chick and grower stages fed on various diet types.

\begin{tabular}{|c|c|c|c|c|c|c|c|}
\hline \multirow{2}{*}{ Parameter } & \multicolumn{5}{|c|}{ Diet Types } & \multirow{2}{*}{ MSE } & \multirow{2}{*}{$p$ Value } \\
\hline & Diet 1 & Diet 2 & Diet 3 & Diet 4 & Diet 5 & & \\
\hline \multicolumn{8}{|c|}{ Feed cost (USD/kg) } \\
\hline Chick & 0.57 & 0.56 & 0.55 & 0.54 & 0.53 & - & - \\
\hline Grower & 0.48 & 0.47 & 0.46 & 0.45 & 0.44 & - & - \\
\hline \multicolumn{8}{|c|}{ ADI (g/bird) } \\
\hline Chicks & 36.20 & 33.82 & 29.81 & 27.20 & 24.68 & 9.1 & $<0.0001$ \\
\hline Grower & 84.56 & 84.31 & 84.36 & 78.27 & 75.20 & 28.8 & 0.055 \\
\hline \multicolumn{8}{|c|}{ Cumulative feed intake (g/bird) } \\
\hline Chick (ADI x 42 days) & 1520.4 & 1420.4 & 1252.0 & 1142.4 & 1036.6 & - & - \\
\hline Grower (ADI x 140 days) & $11,838.4$ & $11,803.4$ & $11,810.4$ & $10,957.8$ & $10,528.9$ & - & - \\
\hline \multicolumn{8}{|c|}{ Cost of feed consumed (USD per bird) } \\
\hline Chick & $0.87^{\mathrm{a}}$ & $0.79^{b}$ & $0.69^{\mathrm{c}}$ & $0.62^{\mathrm{d}}$ & $0.55^{\mathrm{e}}$ & 0.002 & $<0.0001$ \\
\hline Grower & $5.68^{\mathrm{a}}$ & $5.50^{\mathrm{a}}$ & $5.40^{\mathrm{a}}$ & $4.92^{\mathrm{b}}$ & $4.63^{\mathrm{b}}$ & 0.266 & $<0.0001$ \\
\hline Total feed cost & $6.42^{\mathrm{a}}$ & $6.29^{a}$ & $6.09^{\mathrm{a}}$ & $5.54^{\mathrm{b}}$ & $5.18^{\mathrm{b}}$ & 0.361 & $<0.0001$ \\
\hline Live weight at sale of birds ( $\mathrm{g}$ ) & $1260.4^{\mathrm{a}}$ & $1337.5^{\mathrm{a}}$ & $1317.5^{\mathrm{a}}$ & $1235.7^{\mathrm{a}}$ & $1194.3^{b}$ & 14.264 & 0.033 \\
\hline Sale of birds (US\$ per bird) & 6.0 & 6.0 & 6.0 & 6.0 & 6.0 & & \\
\hline Gross profit margin & $-0.41^{\mathrm{e}}$ & $-0.27^{\mathrm{d}}$ & $-0.10^{\mathrm{c}}$ & $0.48^{\mathrm{b}}$ & $0.83^{\mathrm{a}}$ & 0.0001 & $<0.0001$ \\
\hline CBR & $-0.07^{\mathrm{e}}$ & $-0.04^{\mathrm{d}}$ & $-0.02^{\mathrm{c}}$ & $0.09^{b}$ & $0.16^{\mathrm{a}}$ & 0.004 & $<0.0001$ \\
\hline RoI & $-6.45^{\mathrm{e}}$ & $-4.37^{\mathrm{d}}$ & $-1.59^{c}$ & $8.74^{b}$ & $16.05^{a}$ & 0.050 & $<0.0001$ \\
\hline
\end{tabular}

$\mathrm{a}, \mathrm{b}, \mathrm{c}, \mathrm{d}, \mathrm{e}$ Means in a row with different superscript letters are significantly different at $\alpha=0.05$. Exchange rate was equivalent to 1 USD for $100 \mathrm{Ksh}$. BSFLM = black soldier fly larval meal. (-) values were not calculated. The protein cost in the diets was calculated in USD \$/kg, cost of fishmeal (Rastrineobola argentae) $=1.20$ USD; BSFLM $=0.9$ USD. Each bird was sold at USD 6.0.

\section{Discussion}

Here, we present the first report globally on the effects of non-defatted BSF meal as a promising and sustainable alternative nutrient-rich protein additive in commercial IB layer chick and grower diets. Protein is an essential component of poultry diet, which accounts for over $70 \%$ of total production cost needed for nutrition and growth [7]. However, this protein source is critical because it strongly impacts accessibility and ease of use of the essential amino acids [54]. The composition of protein of BSFLM ( $47 \%$ DM) was higher compared to that documented by De Marco et al. [40], Makkar et al. [11] and Onsongo et al. [7]. These variations in CP composition observed among studies can be largely attributed to the substrate (brewers' spent grain) used compared to that reported in previous studies [55]. The methionine content of BSFLM was lower compared to that stated by Onsongo et al. [7] (0.8\%), though higher than that presented by Spranghers et al. [56]. The content of lysine of BSFLM was comparable to that published by Onsongo et al. [7]. Similarly, Newton et al. [57] has demonstrated comparable levels of lysine and methionine in poultry diets. However, lysine and methionine content reported in BSFLM is within the recommended quantity ( 1.00 and $0.38 \mathrm{~g} / \mathrm{g}$, respectively), acceptable for chicken diets [23,58]. The considerable variation in the growth and carcass responses to the various diet types might be attributed to deficiency or imbalance of amino acids and other nutrients, which needs further future research exploration. This might be a particular shortcoming due to the method of diet type preparation. Therefore, future research activities should use more advanced methods to effectively formulate poultry diets based on standardized ileal tract digestible (SID) amino acids (AA) for poultry [31]. Moreover, BSFLM has been shown to exhibit low and variable sulphur amino acids (Met and Cys) concentration and these amino acids are the least digestible [32,33].

Growth rate of chicks provided feeds with higher inclusion levels of BSFLM (50, 75 and $100 \%$ ) was significantly affected. This can be attributed to reduced feed intake observed with the incremental levels of BSFLM as observed in the current study. Besides protein, BSFLM are also known to contain higher levels of chitin than FM (lack chitin), 
which has been shown to increase the fibre content of the diets [11,19]. Diets rich in fiber (chitin) are beneficial for feed application due the influence imposed on the mucosa lining of the intestine, in respective of the amount used [59], but insoluble fractions such as fibre have also been reported to favor the resulting effects on the intestinal mucus barrier of chickens [60]. It is common knowledge that the addition of fiber in ration in low levels poses a good effect but levels exceeding $30 \mathrm{~g} / \mathrm{kg}$ have been shown to negatively impact voluntary uptake of feed and nutrient digestibility [61-63], thus poor performance of birds. This explains why formulated poultry diets should not contain more than $3 \%$ crude fiber, especially for the younger birds (chicks) to allow for improved feed conversion [64]. However, mixing fiber fractions in different feeds would be more effective if further research is undertaken particularly for the emerging commercial insect-based feeds.

The NDF content of the chick diets increased with incremental levels of BSFLM, which was associated with reduced feed intake and could potentially affect the growth of the birds due to higher substitution level of chitin, which has been well documented to lessen digestibility and micronutrient utilization $[65,66]$. This effect is especially pronounced for proteins due to poor digestibility of ADF bound nitrogen [66]. The chicks require more protein than the later stages of growth [23] and therefore are more affected when protein intake and digestibility are affected. Other studies have reported similar results when insect meals are included in poultry diets. For instance, Awoniyi et al. [67] reported negative but insignificant body weight gain at 25\% to 100\% inclusion levels of insects (Musca domestica and Tenebrio molitor) in broiler chicken diet. The reduction of feed intake by birds has also been reported by Mohammed et al. [68], following the incorporation of various levels of BSFLM in their diets.

The FCR values decreased with increase inclusion levels of BSFLM, though there was no significant difference for chicks and growers fed on the various diet types. Contrarily, Amao et al. [68] reported that replacing fishmeal with BSF larvae meal turn to significant increase the FCR values of experimental hens. Chicks fed diets with lower inclusion levels of BSFLM $(25 \%$ BSFLM $+75 \%$ FM and 50\%BSFLM $+50 \%$ FM) were observed to perform better compared to those fed diet with $100 \%$ BSFLM. Previous studies have fed broilers on diets supplemented with Musca domestica [69] and Tenebrio molitor [67,70,71] and demonstrated that the FCR values did not vary $[66,70]$, which is consistent with the current findings. However, additional studies are warranted to establish the impact of BSFLM on long-term growth rate following the incorporation of higher levels of insect protein in animal feeds.

The incorporation of BSFLM in grower diets did not show any significant effect on the overall weight, ADG, ADFI and FCR of the birds subjected to the various feed regimes. Similarly, no negative dietary effects were observed when soybean meal in poultry feed is replaced by defatted BSFLM [72]. Mwaniki et al. [21] also observed an improved feed intake when birds were offered diets with increased insect meals compared to those provided 0 and $50 \%$ inclusion levels of the defatted BSFLM. Marono et al. [20] also reported significant effect of inclusion of BSFLM in laying hens on laying percentage, feed intake, weight gain and egg characteristics. In livestock production including poultry, ADG plays a critical role in growth rate of birds [73]. The effects of diet types did not significantly impact on the ADG of the growing birds, which implies there was adequate supply of nutrients to the birds provided by the various diet types. In this study, the growth rate of growing birds subjected to diets with BSFLM inclusion up to 2.5 and 5.0\% (25 and 50\% replacement of FM) was comparable [74]. However, the discrepancy observed might be attributed to the different strain of birds used in the two experiments.

The FCR of the growers was similar when exposed to the various diet types. Our findings are consistent to that presented by Maurer et al. [72], whereby the feed consumption and FCR of laying hen (Lohmann Leghorn) were unaffected by the experimental diets with BSFLM replacing soybean cake up to $100 \%$. Contrarily, Mwaniki et al. [21], revealed increased feed consumption by the Shaver White Leghorns provided diets with defatted BSFLM. According to Mwaniki et al. [21] and Liu et al. [75], high feed consumption by birds provided insect-based diet might be due to higher fiber content following increase 
inclusion levels of BSFLM. This can be attributed to the fact that fibres help to facilitate increased ceca fermentation in birds [76], thus increased nutrients absorption [77] and better growth. Bovera et al. [78] reported, however, that increased intake of chitin through increased inclusion level of BSFLM played a significant probiotic role in enhancing the weight gain in birds.

During the transition phase of the birds from the chicks to the growers (i.e., between week 10 and 12), there was a period of physical adjustment to the new feeds between week 10 and 12. Leeson and Summers [79] and Mwaniki et al. [21] revealed that birds are usually physically challenged before the onset of egg laying with great potential for negative nutrient balances to occur. This explains why young birds must be provided with adequate energy and nutrient-rich feeds for proper body build up before the onset of egg laying. This may be due to the growth of the digestive system of the grower birds, which is capable of handling more fibrous materials that might have originated from the increased inclusion of BSFLM. Mwaniki et al. [21] emphasized that despite the weight gain at the end of the growing phase of the birds, it is imperative that the feed intake of the birds should be increased as the peak egg laying period approaches.

Generally, the weekly average weight gain of the birds subjected to the various feeding regimes declined consistently from week 15 as they approach the egg laying phase. This is a common trend observed in layer birds and have been shown to have associated benefits during the egg laying phase [80]. Gordon et al. [80] demonstrated the influence of body weight on egg size, revealing that lighter weight hens might turn to produce smaller eggs than heavier hens. However, we are also undertaken further research studies with the same clusters of grower hens to establish if weight gain observed at the grower phase would affect the dynamics of total egg mass production and egg size when the hens are subjected to feeding regimes with varying inclusion levels of BSFLM as well as associated profitability [80-83].

No significant dietary effect was observed on carcass traits (all internal organs, breast meat and drumsticks) of grower pullets except for the dressed carcass weight, thighs, and wings. The weight of body parts of the birds was generally higher for birds that were subjected to diets containing 25, 50 and 75\% BSFLM inclusion ratio compared to the other diets. Several studies have reported an increase in dressed carcass weight of birds when fed on diets with BSFLM at moderate inclusion levels $[7,66]$, while others have shown that dietary regime of birds with BSFLM does not significantly affect the size of the internal organs [74,84] and broiler chickens fed mealworm [85].

Our findings have proven that the price of feeds for the chicks and grower pullets gradually reduces following increment levels of BSFLM substituting FM. Chick and grower diets with $100 \%$ BSFLM inclusion was much cheaper compared to diets with $100 \%$ FM. The results also showed that $100 \%$ FM diet had the least gross profit margin, CBR and RoI compared to the other diet types thus making BSFLM feed more affordable than the conventional FM feed, that heavily depends on fish importation and overfishing in major waters [86]. The low cost of BSFLM is reflected in the reduced cost of feed, increased profits, CBR and RoI compared to FM, which is coherent with the information provided by Khan et al. [86] and Onsongo et al. [7].

\section{Conclusions}

Here, we have demonstrated for the first time that the substitution of the expensive fishmeal in poultry feed by BSFLM does not comprise the overall growth and economic performance of the birds. The variation observed among the various diet types can be attributed to nutrient deficiencies or imbalance in the formulated feeds. The best performing diet mixture was $75 \%$ FM and 25\% BSFLM in terms of the growth performance of the birds but the most cost-effective feed was with 100\% BSFLM inclusion rate. Combining evidence obtained in the present study, it can be speculated that poultry feed supplemented with BSFLM would represents a valuable technology for smallholder farmers and the animal feed industry in developing countries. However, future studies should investigate other 
sustainable solution-oriented approaches such extrusion to increase the nutritional value and digestibility of organic matter and crude protein in BSFLM containing feed blends. Also, future research should formulate poultry diet with BSFLM based on standardized ileal digestibility of amino acids using ideal protein concept as described by Zhang and Adeola [31] to alleviate the effect of protein deficiency during digestibility. A further consideration emerging from this study is the role of BSFLM fat in determining the potential technological quality of the feeds and their impact on poultry growth. Thus, fat content in emerging insect-based poultry feed mixture should be monitored closely to guarantee adequate nutrient supply in the process.

Author Contributions: E.K.S., C.M.T., I.M.O., J.J.A.v.L., and M.D. conceived the experiment; E.K.S., I.M.O. and C.M.T. designed the experiment; software, and C.M.T.; investigation, E.K.S., I.M.O. and C.M.T.; resources, C.M.T.; writing-original draft preparation, E.K.S., I.M.O., J.G.C., and C.M.T.; writing-review and editing, E.K.S., I.M.O., M.K.A., J.G.C., D.M.M., S.S., D.S., P.A.O.A., M.G., J.J.A.v.L., M.D., C.M.T.; visualization, D.S. and C.M.T.; supervision, I.M.O., M.K.A., and C.M.T.; project administration, C.M.T.; funding acquisition, J.J.A.v.L., C.M.T., M.D. All authors have read and agreed to the published version of the manuscript.

Funding: This research received financial support from the Norwegian Agency for Development Cooperation, the Section for research, innovation, and higher education grant number RAF-3058 KEN18/0005 (CAP-Africa), Netherlands Organization for Scientific Research, WOTRO Science for Global Development (NWO-WOTRO) (ILIPA-W 08.250.202), the Canadian International Development Research Centre (IDRC) and the Australian Centre for International Agricultural Research (ACIAR) (INSFEED-Phase 2: Cultivate Grant No: 108866-001), and Rockefeller Foundation (SiPFeed-Grant No: 2018 FOD 009) through the International Centre of Insect Physiology and Ecology (icipe). We also gratefully acknowledge the support of icipe core funding provided by United Kingdom's Foreign, Commonwealth and Development Office (FCDO); the Swedish International Development Cooperation Agency (Sida); the Swiss Agency for Development and Cooperation (SDC); the Federal Democratic Republic of Ethiopia; and the Government of the Republic of Kenya. The funders had no role in study design, data collection and analysis, decision to publish, or preparation of the manuscript. Therefore, the views expressed herein do not necessarily reflect the official opinion of the donors.

Institutional Review Board Statement: Ethical approval for the study was provided by the Institutional Animal Care and Use Committee (IACUC) of Kenya Agricultural and Livestock Research Organization (KALRO)-Veterinary Science Research Institute (VSRI); approval Code No.: KALROVSRI/IACUC019/30082019.

Informed Consent Statement: Not applicable.

Data Availability Statement: All datasets presented in this study are included in the article and can be availed by the authors upon reasonable request.

Acknowledgments: We would like to thank all the technical staff of ICIPE and KALRO for their commitment and support, which was instrumental in contributing consistently to the realization of this study.

Conflicts of Interest: The authors have declared no conflict of interest.

\section{References}

1. Omiti, M.J.; Okuthe, S.O. An Overview of the Poultry Sector and Status of Highly Pathogenic Avian Influenza (HPAI) in Kenya; Africa/Indonesia Team Working Paper No. 4; International Food Policy Research Institute (IFPRI): Washington, DC, USA, 2009; p. 117.

2. FAO. World Livestock 2011: Livestock in Food Security; Food and Agriculture Organization of the United Nations: Rome, Italy, 2011.

3. UN (United Nations). World Population Prospects 2019: Highlights; United Nations Department of Economic and Social Affairs. Available online: https: / www.un.org/development/desa/publications /world-population-prospects-2019-highlights.html. (accessed on 1 March 2021).

4. Olawumi, S.O.; Adeoti, A.I. Comparative Economic Analysis of Black and Brown Commercial Layer Strains in Nigeria. Int. J. Poult. Sci. 2009, 8, 1011-1013. [CrossRef]

5. Van Huis, A.; Van Itterbeeck, J.; Klunder, H.; Mertens, E.; Halloran, A.; Muir, G.; Vantomme, P. Edible Insects: Future Prospects for Food and Feed Security; FAO Forestr. Paper 171; Food and Agriculture Organization of the United Nations: Rome, Italy, 2013. 
6. Al-Qazzaz, M.F.A.; Ismail, D.; Akit, H.; Idris, L.H. Effect of using insect larvae meal as a complete protein source on quality and productivity characteristics of laying hens. R. Bras. Zootec. 2016, 45, 518-523. [CrossRef]

7. Onsongo, V.O.; Osuga, I.M.; Gachuiri, C.K.; Wachira, A.M.; Miano, D.M.; Tanga, C.M.; Ekesi, S.; Nakimbugwe, D.; Fiaboe, K.K.M. Insects for Income Generation Through Animal Feed: Effect of Dietary Replacement of Soybean and Fish Meal With Black Soldier Fly Meal on Broiler Growth and Economic Performance. J. Econ. Entomol. 2018, 111, 1966-1973. [CrossRef] [PubMed]

8. Kenya Market-led Dairy Programme Phase II (KMDP II). SNV Kenya Positioning Paper Diary Sector (Revised November 2014). Available online: https: / $/$ www.google.com/url?sa=t\&rct=j\&q=\&esrc=s\&source=web\&cd=\&ved=2ahUKEwiehNGYubwAhWhxYsBHa05BBcQFjAAegQIBRAD\&url=https $\% 3 \mathrm{~A} \% 2 \mathrm{~F} \% 2 \mathrm{Fcowsoko.com} \% 2 \mathrm{Fprograms} \% 2 \mathrm{Fkmdp} \% 2 \mathrm{Fpublications} \%$ 2F73\%2Fitem\&usg=AOvVaw3RG9IaezDEZ81c34bB2yRJ (accessed on 28 February 2021).

9. Munguti, J.M.; Liti, D.M.; Waidbacher, H.; Straif, M.; Zollitsch, W. Proximate composition of selected potential feedstuffs for Nile tilapia (Oreochromis niloticus Linnaeus) production in Kenya. Aust. J. Agric. Res. 2006, 57, 131-141.

10. Maina, J.G.; Beames, R.M.; Higgs, D.; Mbugua, P.N.; Iwama, G.; Kisia, S.M. The Feeding Value and Protein Quality in High-Fibre and Fibre-Reduced Sunflower Cakes and Kenya's "Omena" Fishmeal for Tilapia (Oreochromis niloticus). Livest. Res. Rural. Dev. 2007, 19. Available online: http:/ / www.lrrd.org/lrrd19/11/main19164.htm (accessed on 3 November 2020).

11. Makkar, H.P.; Tran, G.; Heuzé, V.; Ankers, P. State-of-the-art on use of insects as animal feed. Anim. Feed Sci. Technol. 2014, 197, 1-33. [CrossRef]

12. Muin, H.; Taufek, N.M.; Kamarudin, M.S.; Razak, S.A. Growth performance, feed utilization and body composition of Nile tilapia, Oreochromis niloticus (Linnaeus, 1758) fed with different levels of black soldier fly, Hermetia illucens (Linnaeus, 1758) maggot meal diet. Iran. J. Fish. Sci. 2017, 16, 567-577.

13. Chia, S.Y.; Tanga, C.M.; Osuga, I.M.; Alaru, A.O.; Mwangi, D.M.; Githinji, M.; Subramanian, S.; Fiaboe, K.K.M.; Ekesi, S.; Van Loon, J.J.A.; et al. Effect of Dietary Replacement of Fishmeal by Insect Meal on Growth Performance, Blood Profiles and Economics of Growing Pigs in Kenya. Animals 2019, 9, 705. [CrossRef]

14. Van Huis, A. Potential of Insects as Food and Feed in Assuring Food Security. Annu. Rev. Entomol. 2013, 58, 563-583. [CrossRef]

15. Mancuso, T.; Baldi, L.; Gasco, L. An empirical study on consumer acceptance of farmed fish fed on insect meals: The Italian case. Aquac. Int. 2016, 24, 1489-1507. [CrossRef]

16. Chia, S.Y.; Tanga, C.M.; Osuga, I.M.; Mohamed, S.A.; Khamis, F.M.; Salifu, D.; Sevgan, S.; Fiaboe, K.K.; Niassy, S.; Van Loon, J.J.; et al. Effects of waste stream combinations from brewing industry on performance of Black Soldier Fly, Hermetia illucens (Diptera: Stratiomyidae). PeerJ 2018, 6, e5885. [CrossRef]

17. Shumo, M.; Osuga, I.M.; Khamis, F.M.; Tanga, C.M.; Fiaboe, K.K.M.; Subramanian, S.; Ekesi, S.; Van Huis, A.; Borgemeister, C. The nutritive value of black soldier fly larvae reared on common organic waste streams in Kenya. Sci. Rep. 2019, 9, 10110. [CrossRef] [PubMed]

18. Pinotti, L.; Giromini, C.; Ottoboni, M.; Tretola, M.; Marchis, D. Review: Insects and former foodstuffs for upgrading food waste biomasses / streams to feed ingredients for farm animals. Animals 2019, 13, 1365-1375. [CrossRef]

19. Marono, S.; Loponte, R.; Lombardi, P.; Vassalotti, G.; Pero, M.E.; Russo, F.; Gasco, L.; Parisi, G.; Piccolo, G.; Nizza, S.; et al. Productive performance and blood profiles of laying hens fed Hermetia illucens larvae meal as total replacement of soybean meal from 24 to 45 weeks of age. Poult. Sci. 2017, 96, 1783-1790. [CrossRef] [PubMed]

20. Mwaniki, Z.; Neijat, M.; Kiarie, E. Egg production and quality responses of adding up to $7.5 \%$ defatted black soldier fly larvae meal in a corn-soybean meal diet fed to Shaver White Leghorns from week 19 to 27 of age. Poult. Sci. 2018, 97, 2829-2835. [CrossRef] [PubMed]

21. Secci, G.; Bovera, F.; Nizza, S.; Baronti, N. Quality of eggs from Lohmann Brown classic laying hens fed black soldier fly meal as substitute for soya bean. Animals 2018, 12, 2191-2197. [CrossRef] [PubMed]

22. National Research Council (NRC). Nutrient Requirements of Poultry, 9th ed.; National Academy Press: Washington, DC, USA, 1994

23. Swatson, H.K.; Iji, P.A.; Gous, R.M. Body Growth, Visceral Organ Weight and Intestinal Digestive Enzyme Fchickens on Diets Varying in Energy and Protein Contents. J. Anim. Vet. Adv. 2003, 2, 305-311.

24. Butzen, F.M.; Ribeiro, A.M.L.; Vieira, M.M.; Kessler, A.M.; DaDalt, J.C.; Della, M.P. Early feed restriction in broilers. I-Performance, body fraction weights, and meat quality. J. Appl. Poult. Res. 2013, 22, 251-259. [CrossRef]

25. Obeng, A.S.; Rickard, H.; Ndi, O.; Sexton, M.; Barton, M. Comparison of antimicrobial resistance patterns in enterococci from intensive and free range chickens in Australia. Avian Pathol. 2013, 42, 45-54. [CrossRef]

26. Federation of Animal Science Societies (FASS). Guide for the Care and Use of Agricultural Animals in Agricultural Research and Teaching, 3rd ed.; FASS: Champaign, IL, USA, 2010.

27. Lindahl, J.F.; Young, J.; Wyatt, A.; Young, M.; Alders, R.; Bagnol, B.; Kibaya, A.; Grace, D. Do vaccination interventions have effects? A study on how poultry vaccination interventions change smallholder farmer knowledge, attitudes, and practice in villages in Kenya and Tanzania. Trop. Anim. Health Prod. 2018, 51, 213-220. [CrossRef]

28. Boccazzi, I.V.; Ottoboni, M.; Martin, E.; Comandatore, F.; Vallone, L.; Spranghers, T.; Eeckhout, M.; Mereghetti, V.; Pinotti, L.; Epis, S. A survey of the mycobiota associated with larvae of the black soldier fly (Hermetia illucens) reared for feed production. PLoS ONE 2017, 12, e0182533. [CrossRef]

29. Khamis, F.M.; Ombura, F.L.O.; Akutse, K.S.; Subramanian, S.; Mohamed, S.A.; Fiaboe, K.K.M.; Saijuntha, W.; Van Loon, J.J.A.; Dicke, M.; Dubois, T.; et al. Insights in the Global Genetics and Gut Microbiome of Black Soldier Fly, Hermetia illucens: Implications for Animal Feed Safety Control. Front. Microbiol. 2020, 11, 1538. [CrossRef] [PubMed] 
30. Zhang, F.; Olayiwola, A. Techniques for evaluating digestibility of energy, amino acids, phosphorus, and calcium in feed ingredients for pigs. Anim. Nutr. 2017, 3, 344-352. [CrossRef] [PubMed]

31. Schiavone, A.; De Marco, M.; Martínez, S.; Dabbou, S.; Renna, M.; Madrid, J.; Hernandez, F.; Rotolo, L.; Costa, P.; Gai, F.; et al. Nutritional value of a partially defatted and a highly defatted black soldier fly larvae (Hermetia illucens L.) meal for broiler chickens: Apparent nutrient digestibility, apparent metabolizable energy and apparent ileal amino acid digestibility. J. Anim. Sci. Biotechnol. 2017, 8, 1-9. [CrossRef] [PubMed]

32. Mwaniki, Z.; Kiarie, E. Standardized ileal digestible amino acids and apparent metabolizable energy content in defatted black soldier fly larvae meal fed to broiler chickens. Can. J. Anim. Sci. 2019, 99, 211-217. [CrossRef]

33. Landry, J.; Delhaye, S. Simplified procedure for the determination of tryptophan of foods and feedstuffs from barytic hydrolysis. J. Agric. Food Chem. 1992, 40, 776-779. [CrossRef]

34. Bech-Andersen, S. Determination of Tryptophan with HPLC after Alkaline Hydrolysis in Autoclave using $\alpha$-methyl-tryptophan as Internal Standard. Acta Agric. Scand. 1991, 41, 305-309. [CrossRef]

35. Slump, P.; Flissebaalje, T.D.; Haaksman, I.K. Tryptophan in food proteins: A comparison of two hydrolytic procedures. J. Sci. Food Agric. 1991, 55, 493-496. [CrossRef]

36. AOAC. Official Methods of Analysis of AOAC International, 16th ed.; AOAC International Arlington: Virginia, VA, USA, 1988.

37. Rosales, C.J.; Jorna, R.; Faber, N.; van Haren, R.A. Knowledge approach to sustainable agriculture. In Global Food Insecurity. Rethinking Agricultural and Development Paradigm and Policy; Behnassi, M., Draggan, S., Yaya, S., Eds.; Springer: Dordrecht, The Netherlands, 2011.

38. Núñez-Sánchez, N.; Marín, A.L.M.; Hernández, M.P.; Carrion, D.; Gómez, C.G.; Alba, L.M.P. Faecal near infrared spectroscopy (NIRS) as a tool to assess rabbit's feed digestibility. Livest. Sci. 2012, 150, 386-390. [CrossRef]

39. De Marco, M.; Martínez, S.; Hernandez, F.; Madrid, J.; Gai, F.; Rotolo, L.; Belforti, M.; Bergero, D.; Katz, H.; Dabbou, S.; et al. Nutritional value of two insect larval meals (Tenebrio molitor and Hermetia illucens) for broiler chickens: Apparent nutrient digestibility, apparent ileal amino acid digestibility and apparent metabolizable energy. Anim. Feed Sci. Technol. 2015, 209, 211-218. [CrossRef]

40. Llames, C.R.; Fontaine, J. Determination of Amino Acids in Feeds: Collaborative Study. J. AOAC Int. 1994, $77,1362-1402$. [CrossRef]

41. Windham, W.R. AOAC official method 994.12, amino acids in feeds, alternative III, acid hydrolysis method. In Official methods of Analysis of AOAC Intemational, 16th ed.; Cunniff, P., Ed.; AOAC International: Rockville, MD, USA, 1995; Volume 1.

42. Powell, S.; Bidner, T.D.; Southern, L.L. Effects of glycine supplementation at varying levels of methionine and cystine on the growth performance of broilers fed reduced crude protein diets. Poult. Sci. 2011, 90, 1023-1027. [CrossRef]

43. Powell, C.D.; Chowdhury, M.A.K.; Bureau, D.P. Assessing the bioavailability of L-methionine and a methionine hydroxy analogue (MHA-Ca) compared to DL-methionine in rainbow trout (Oncorhynchus mykiss). Aquac. Res. 2015, 48, 332-346. [CrossRef]

44. Zampiga, M.; Laghi, L.; Petracci, M.; Zhu, C.; Meluzzi, A.; Dridi, S.; Sirri, F. Effect of dietary arginine to lysine ratios on productive performance, meat quality, plasma and muscle metabolomics profile in fast-growing broiler chickens. J. Anim. Sci. Biotechnol. 2018, 9, 79. [CrossRef] [PubMed]

45. Al-Sagan, A.; Khalil, S.; Smith, M. The Benefit of L-Threonine Supplementation on Growth Performance, Carcass Characteristics, Intestinal Morphology and Litter Quality of Broilers. Braz. J. Poult. Sci. 2018, 20, 753-758. [CrossRef]

46. Barałkiewicz, D.; Kanecka-Hanc, A.; Gramowska, H. ICP slurry introduction for simple and rapid determination of Pb, Mg and Ca in plant roots. Open Chem. 2007, 5, 1148-1157. [CrossRef]

47. Dos Santos, E.J.; Baika, L.M.; Herrmann, A.B.; Kulik, S.; Sato, C.S.; Dos Santos, A.B.; Curtius, A.J. Fast assessment of mineral constituents in grass by inductively coupled plasma optical emission spectrometry. Braz. Arch. Biol. Technol. 2012, 55, 457-464. [CrossRef]

48. Vudagandla, S.; Kumar, N.S.; Dharmendra, V.; Asif, M.; Balaram, V.; Zhengxu, H.; Zhen, Z. Determination of Boron, Phosphorus, and Molybdenum Content in Biosludge Samples by Microwave Plasma Atomic Emission Spectrometry (MP-AES). Appl. Sci. 2017, 7, 264. [CrossRef]

49. Płotka-Wasylka, J.; Frankowski, M.; Simeonov, V.; Polkowska, Ż.; Namieśnik, J. Determination of Metals Content in Wine Samples by Inductively Coupled Plasma-Mass Spectrometry. Molecules 2018, 23, 2886. [CrossRef]

50. Leeson, S.; Summers, J.D. Effect of Immature Body Weight on Laying Performance. Poult. Sci. 1987, 66, 1924-1928. [CrossRef]

51. Aok, Y.M.D. Effect of Feed Enzymes and Energy Level on Broiler Chicken (Gallus domesticus) Performance in Kenya. Master's Thesis, University of Nairobi, Nairobi, Kenya, 2012.

52. Venables, B.; Hornik, K.; Maechler, M. Polynom: A Collection of Functions to Implement a Class for Univariate Polynomial Manipulations; R Package Version 1.4-0; 2019. Available online: https:/ /rdrr.io/cran/polynom/ (accessed on 22 April 2021).

53. Wallace, P.A.; Nyameasem, J.K.; Adu-Aboagye, G.A.; Affedzie-Obresi, S.; Nkegbe, E.K.; Karbo, N.; Murray, F.; Leschen, W.; Maquart, P.-O. Impact of black soldier fly larval meal on growth performance, apparent digestibility, haematological and blood chemistry indices of guinea fowl starter keets under tropical conditions. Trop. Anim. Health Prod. 2017, 49, 1163-1169. [CrossRef]

54. Tschirner, M.; Simon, A. Influence of different growing substrates and processing on the nutrient composition of black soldier fly larvae destined for animal feed. J. Insects Food Feed 2015, 1, 249-259. [CrossRef] 
55. Spranghers, T.; Ottoboni, M.; Klootwijk, C.; Ovyn, A.; Deboosere, S.; De Meulenaer, B.; Michiels, J.; Eeckhout, M.; De Clercq, P.; De Smet, S. Nutritional composition of black soldier fly (Hermetia illucens) prepupae reared on different organic waste substrates. J. Sci. Food Agric. 2017, 97, 2594-2600. [CrossRef]

56. Newton, G.L.; Booram, C.V.; Barker, R.W.; Hale, O.M. Dried Hermetia Illucens Larvae Meal as a Supplement for Swine. J. Anim. Sci. 1977, 44, 395-400. [CrossRef]

57. Boland, M.J.; Rae, A.N.; Vereijken, J.M.; Meuwissen, M.P.; Fischer, A.R.; van Boekel, M.A.; Rutherfurd, S.M.; Gruppen, H.; Moughan, P.J.; Hendriks, W.H. The future supply of animal-derived protein for human consumption. Trends Food Sci. Technol. 2013, 29, 62-73. [CrossRef]

58. Ramachandran, N.K.; Mathew, P.; Madhavan, P.; Prabhu, P. Chitin as a feed additive for broiler chicken. Indian J. Poult. Sci. 1987, $22,40-44$.

59. Montagne, L.; Pluske, J.; Hampson, D. A review of interactions between dietary fibre and the intestinal mucosa, and their consequences on digestive health in young non-ruminant animals. Anim. Feed Sci. Technol. 2003, 108, 95-117. [CrossRef]

60. Ozimek, L.; Sauer, W.C.; Kozikowski, V.; Ryan, J.K.; Jorgensen, H.; Jelenv, P. Nutritive value of protein extracted from honeybees. J. Food Sci. 1985, 50, 1327-1329. [CrossRef]

61. Kroeckel, S.; Harjes, A.-G.; Roth, I.; Katz, H.; Wuertz, S.; Susenbeth, A.; Schulz, C. When a turbot catches a fly: Evaluation of a pre-pupae meal of the Black Soldier Fly (Hermetia illucens) as fish meal substitute-Growth performance and chitin degradation in juvenile turbot (Psetta maxima). Aquaculture 2012, 364, 345-352. [CrossRef]

62. Marono, S.; Piccolo, G.; Loponte, R.; Di Meo, C.; Attia, Y.A.; Nizza, A.; Bovera, F. In Vitro Crude Protein Digestibility of Tenebrio molitor and Hermetia illucens Insect Meals and its Correlation with Chemical Composition Traits. Ital. J. Anim. Sci. 2015, 14, 338-343. [CrossRef]

63. Tejeda, O.; Kim, W. Role of Dietary Fiber in Poultry Nutrition. Animals 2021, 11, 461. [CrossRef]

64. Newton, G.L.; Sheppard, D.C.; Watson, D.W.; Burtle, G.J.; Dove, C.R.; Tomberlin, J.K.; Thelen, E.E. Black soldier fly Hermetia illucens as a manure management resource recovery tool. Proceeding of the Symposium on the State of the Science of Animal Manure and Waste Management, San Antonio, TX, USA, 5-7 January 2005.

65. Pretorius, Q. The Evaluation of Larvae of Musca domestica (Common House Fly) as Protein Source for Broiler Production. Master's Thesis, Stellenbosch University, Stellenbosch, South Africa, 2011.

66. Awoniyi, T.A.M.; Aletor, V.A.; Aina, J.M. Performance of broiler chickens fed on maggot meal in place of fishmeal. Int. J. Poult. Sci. 2003, 2, 271-274.

67. Mohammed, A.; Laryea, T.E.; Ganiyu, A.; Adongo, T. Effect of black soldier fly (Hermetia illucens) larvae meal on the growth performance of broiler chicken. Int. J. Dev. 2017, 4. Available online: http:/ / www.udsijd.org (accessed on 22 April 2021).

68. Amao, O.; Oladunjoye, I.; Togun, V.; Olubajo, K.; Oyaniyi, O. Effect of Westwood (Cirina forda) Larva Meal on the Laying Performance and Egg Characteristics of Laying Hen in a Tropical Environment. Int. J. Poult. Sci. 2010, 9, 450-454. [CrossRef]

69. Ocio, E.; Viñaras, R. Rey House fly larvae meal grown on municipal organic waste as a source of protein in poultry diets. Anim. Feed Sci. Technol. 1979, 4, 227-231. [CrossRef]

70. Dordevic, M.; Radenkovic-Damnjanovic, B.; Vucinic, M.; Baltic, M.; Teodorovic, R.; Jankovic, L.; Vukasinovic, M.; Rajkovic, M. Effect of the substitution of fish meal with fresh and dehydrated larvae of the house fly (Musca domestica L.) on productive performance and health of broilers. Acta Vet. 2008, 58, 357e68.

71. Maurer, V.; Holinger, M.; Amsler, Z.; Früh, B.; Wohlfahrt, J.; Stamer, A.; Leiber, F. Replacement of soybean cake by Hermetia illucens meal in diets for layers. J. Insects Food Feed 2016, 2, 83-90. [CrossRef]

72. Wu, X.; Xie, C.; Long, C.; Li, J.; Zhou, X.; Fan, Z.; Blachier, F.; Yin, Y. Effects of a daily three-meal pattern with different dietary protein contents on pig growth performance, carcass and muscle quality traits. J. Sci. Food Agric. 2017, 98, 415-421. [CrossRef] [PubMed]

73. Mbhele, F.G.T.; Mnisi, C.M.; Mlambo, V. A Nutritional Evaluation of Insect Meal as a Sustainable Protein Source for Jumbo Quails: Physiological and Meat Quality Responses. Sustainability 2019, 11, 6592. [CrossRef]

74. Liu, S.; Sun, J.; Yu, L.; Zhang, C.; Bi, J.; Zhu, F.; Qu, M.; Jiang, C.; Yang, Q. Extraction and Characterization of Chitin from the Beetle Holotrichia parallela Motschulsky. Molecules 2012, 17, 4604-4611. [CrossRef]

75. Kiarie, E.; Romero, L.; Ravindran, V. Growth performance, nutrient utilization, and digesta characteristics in broiler chickens fed corn or wheat diets without or with supplemental xylanase. Poult. Sci. 2014, 93, 1186-1196. [CrossRef] [PubMed]

76. Metzler-Zebeli, B.U.; Hooda, S.; Mosenthin, R.; Gänzle, M.G.; Zijlstra, R.T. Bacterial fermentation affects net mineral flux in the large intestine of pigs fed diets with viscous and fermentable nonstarch polysaccharides. J. Anim. Sci. 2010, 88, $3351-3362$. [CrossRef] [PubMed]

77. Bovera, F.; Loponte, R.; Marono, S.; Piccolo, G.; Parisi, G.; Iaconisi, V.; Gasco, L.; Nizza, A. Use of Tenebrio molitor larvae meal as protein source in broiler diet: Effect on growth performance, nutrient digestibility, and carcass and meat traits. J. Anim. Sci. 2016, 94, 639-647. [CrossRef] [PubMed]

78. Leeson, S.; Summers, J.D. Commercial Poultry Nutrition, 5th ed.; University Books: Guelph, ON, Canada, 2005.

79. Gordon, R.; Bryant, M.M.; Roland, D.A. Performance and profitability of second-cycle laying hens as influenced by body weight and body weight reduction during molt. J. Appl. Poult. Res. 2009, 18, 223-231. [CrossRef]

80. Bish, C.L.; Beane, W.L.; Ruszler, P.L.; Cherry, J.A. Body Weight Influence on Egg Production. Poult. Sci. 1985, 64, 2259-2262. [CrossRef] 
81. Lacin, E.; Yildiz, A.; Esenbuga, N.; Macit, M. Effects of differences in the initial body weight of groups on laying performance and egg quality parameters of Lohmann laying hens. Czech J. Anim. Sci. 2008, 53, 466-471. [CrossRef]

82. Datta, R.K.; Islam, M.S.; Kabir, A. Assessment of the production performance and economic efficiencies of available chicken breeds (Gallus domesticus L.) in Rajshahi, Bangladesh. Univ. J. Zool. Rajshahi Univ. 2013, 31, 13-18. [CrossRef]

83. Cullere, M.; Tasoniero, G.; Giaccone, V.; Miotti-Scapin, R.; Claeys, E.; De Smet, S.; Zotte, A.D. Black soldier fly as dietary protein source for broiler quails: Apparent digestibility, excreta microbial load, feed choice, performance, carcass and meat traits. Animals 2016, 10, 1923-1930. [CrossRef]

84. Masoero, F.; Pulimeno, A.M.; Rossi, F. Effect of extrusion, expansion and toasting on the nutritional value of peas, faba beans and lupins. Ital. J. Anim. Sci. 2005, 4, 177-189. [CrossRef]

85. Kolding, J.; Medard, M.; Mkumbo, O.; van Zwieten, P.A.M.; Welcomme, R.L.; Valbo-Jørgensen, J.; Halls, A.S. Status, trends and management of the Lake Victoria Fisheries. Inland Fisheries Evolution and Management-Case Studies from Four Continents; FAO Fisheries and Aquaculture Technical Paper 579. 2014. Available online: http://www.fao.org/3/a-bl763e.pdf. (accessed on 22 April 2021).

86. Khan, S.; Naz, S.; Sultan, A.; Alhidary, I.A.; Abdelrahman, M.; Khan, R.; Khan, N.; Khan, M.; Ahmad, S. Worm meal: A potential source of alternative protein in poultry feed. World's Poult. Sci. J. 2016, 72, 93-102. [CrossRef] 